\title{
Rabbit models: ideal for imaging purposes?
}

\author{
A. van der Laarse $\cdot$ E. E. van der Wall
}

Published online: 16 December 2008

(C) The Author(s) 2008. This article is published with open access at Springerlink.com

In translational medical research, experimental animal models play a prominent role in elucidating physiological and pathophysiological mechanisms involved in human disease. As to cardiac function, the technique to perfuse the isolated heart in vitro has had tremendous impact for more than 100 years [1]. With regard to acute, subacute, and chronic myocardial infarction, animal models predominantly employed large animals like dogs and pigs. More recently also rabbits, rats and mice were employed, as these models benefit from low costs, large numbers of experiments, and ease of housing the animals during the experiment. An additional advantage of the use of small animals is the lower risk of ventricular fibrillation after coronary occlusion and reperfusion in small animals rather than in large animals, leading to less drop outs from the experiment. A large disadvantage of the use of small animals is the lack of dedicated imaging instruments, such as multi-slice computed tomography (MSCT) [2-13], radionuclide imaging and positron emitting tomography (PET) [14-20] and magnetic resonance

Editorial comment to the paper entitled "A modified rabbit model of reperfused myocardial infarction for cardiac MR imaging research" by Feng et al. Doi: 10.1007/s10554-0089393-2.

A. van der Laarse $\cdot$ E. E. van der Wall ( $\square)$ Department of Cardiology, Leiden University Medical Center, P.O. Box 9600, Leiden, The Netherlands e-mail: e.e.van_der_wall@lumc.nl imaging (MRI) [21-33], which are successfully being used in humans.

At present these advanced imaging modalities can also be applied in myocardial infarction studies in small animals. For example, in a study on cardiac function of ischemic hearts before and after intramyocardially administered mesenchymal stem cells in mice in vivo, Grauss et al. [34, 35] used a 9.4 Tesla MR apparatus with a vertical bore (diameter $89 \mathrm{~mm}$ ) normally used for characterization of chemical compounds. Although MR images had high quality, the use of these apparatus for ischemic heart research in small experimental animals is very complicated and only successful after long and intensive training.

The present paper by Feng et al. [36] presents an animal model of myocardial ischemia and reperfusion in rabbits studied in a clinical 1.5 Tesla MRI scanner. In anesthetised rabbits on artificial respiration the thorax was opened, the left circumflex coronary artery branch was ligated by a suture with a slip knot, and reperfused 90 min later by pulling the suture in the closed-chest condition. After injection of $0.3 \mathrm{mmol} / \mathrm{kg}$ of gadolinium-DTPA, myocardial area and myocardial volume showing delayed contrast enhancement were quantified. These data was correlated to the classical histochemical data of infarcted area and volumes, and found to correlate well. The authors were also able to quantify end-systolic and end-diastolic volumes, to calculate stroke volume and ejection fraction. Thus, using a clinical MRI scanner, the normal and post-infarct reperfused rabbit heart 
in vivo can be studied for left ventricular function and infarct size. This research group has a track record in developing novel contrast agents for MRI purposes, particularly porphyrin and nonporphyrin necrosisavid contrast agents (NACAs). It was shown that this rabbit model with reperfused myocardial infarction allows the study of a novel infarct-avid tracer using a clinical MRI scanner. The choice of rabbits is an excellent one for several reasons: (1) the heart rate of anesthetised rabbits is not beyond the range of human heart rates, implying that ECG-triggering does not lead to major problems, (2) the rabbit myocardium has a positive force-frequency relation, (3) rabbits are relatively inexpensive, (4) an entire transverse section of the heart can be placed and observed on a standard microscope glass slide, and (5) there are rabbit strains with heritable hyperlipidemia, such as the Watanabe strain, allowing studies in hearts with coronary atherosclerosis. As also mentioned by the authors, image quality can be improved further by optimizing the "human" cMRI sequences for the rabbit heart.

The present study clearly demonstrates that a nottoo-small experimental animal, the rabbit, can be usefully studied in a clinical MRI scanner, thereby contributing to cost-effectiveness of animal studies. The acquired images are outstanding and provide results that correlated well with histochemical analyses, thereby contributing to the accuracy. As a result, rabbit models are very suitable for imaging purposes. When further optimizing imaging quality, they might become ideal.

Open Access This article is distributed under the terms of the Creative Commons Attribution Noncommercial License which permits any noncommercial use, distribution, and reproduction in any medium, provided the original author(s) and source are credited.

\section{References}

1. Langendorff $O$ (1895) Untersuchungen am überlebenden Säugetierherzen. Pflügers Arch Physiol 61:291-332

2. van Werkhoven JM, Schuijf JD, Jukema JW et al (2008) Anatomic correlates of a normal perfusion scan using 64slice computed tomographic coronary angiography. Am J Cardiol 101:40-45

3. Schuijf JD, Pundziute G, Jukema JW et al (2006) Diagnostic accuracy of 64-slice multislice computed tomography in the noninvasive evaluation of significant coronary artery disease. Am J Cardiol 98:145-148
4. Schuijf JD, Wijns W, Jukema JW et al (2006) Relationship between noninvasive coronary angiography with multislice computed tomography and myocardial perfusion imaging. J Am Coll Cardiol 48:2508-2514

5. Jongbloed MR, Lamb HJ, Bax JJ et al (2005) Noninvasive visualization of the cardiac venous system using multislice computed tomography. J Am Coll Cardiol 45:749-753

6. Pundziute G, Schuijf JD, Jukema JW et al (2007) Prognostic value of multislice computed tomography coronary angiography in patients with known or suspected coronary artery disease. J Am Coll Cardiol 49:62-70

7. Henneman MM, Schuijf JD, Pundziute G et al (2008) Noninvasive evaluation with multislice computed tomography in suspected acute coronary syndrome: plaque morphology on multislice computed tomography versus coronary calcium score. J Am Coll Cardiol 52:216-222

8. van Lennep JE, Westerveld HT, van Lennep HW, Zwinderman AH, Erkelens DW, van der Wall EE (2000) Apolipoprotein concentrations during treatment and recurrent coronary artery disease events. Arterioscler Thromb Vasc Biol 20:2408-2413

9. de Leeuw JG, Wardeh A, Sramek A, van der Wall EE (2007) Pseudo-aortic dissection after primary PCI. Neth Heart J 15:265-266

10. Molhoek SG, Bax JJ, Bleeker GB et al (2004) Comparison of response to cardiac resynchronization therapy in patients with sinus rhythm versus chronic atrial fibrillation. Am J Cardiol 94:1506-1509

11. Braun S, van der Wall EE, Emanuelsson S, Kobrin I (1996) Effects of a new calcium antagonist, mibefradil (Ro 405967), on silent ischemia in patients with stable chronic angina pectoris: a multicenter placebo-controlled study. The mibefradil international study group. J Am Coll Cardiol 27:317-322

12. Schuijf JD, Pundziute G, Jukema JW et al (2007) Evaluation of patients with previous coronary stent implantation with 64-section CT. Radiology 245:416-423

13. Schuijf JD, Bax JJ, van der Wall EE (2007) Anatomical and functional imaging techniques: basically similar or fundamentally different? Neth Heart J 15:43-44

14. van der Wall EE, Heidendal GA, den Hollander W, Westera G, Roos JP (1980) I-123 labeled hexadecenoic acid in comparison with Thallium-201 for myocardial imaging in coronary heart disease. A preliminary study. Eur J Nucl Med 5:401-405

15. van Eck-Smit BL, van der Wall EE, Kuijper AF, Zwinderman AH, Pauwels EK (1993) Immediate thallium-201 reinjection following stress imaging: a time-saving approach for detection of myocardial viability. J Nucl Med 34:737-743

16. Bavelaar-Croon CD, Pauwels EK, van der Wall EE (2001) Gated single-photon emission computed tomographic myocardial imaging: a new tool in clinical cardiology. Am Heart J 14:383-390

17. Bavelaar-Croon CD, Kayser HW, van der Wall EE et al (2000) Left ventricular function: correlation of quantitative gated SPECT and MR imaging over a wide range of values. Radiology 217:572-575

18. Slart RH, Bax JJ, van Veldhuisen DJ, van der Wall EE, Dierckx RA, Jager PL (2006) Imaging techniques in 
nuclear cardiology for the assessment of myocardial viability. Int J Cardiovasc Imaging 22:63-80

19. Slart RH, Bax JJ, van Veldhuisen DJ, van der Wall EE, Dierckx RA, de Boer J, Jager PL (2006) Prediction of functional recovery after revascularization in patients with coronary artery disease and left ventricular dysfunction by gated FDG-PET. J Nucl Cardiol 13:210-219

20. Siebelink HM, Blanksma PK, Crijns HJ et al (2001) No difference in cardiac event-free survival between positron emission tomography-guided and single-photon emission computed tomography-guided patient management: a prospective, randomized comparison of patients with suspicion of jeopardized myocardium. J Am Coll Cardiol 37:81-88

21. Holman ER, Buller VG, de Roos A et al (1997) Detection and quantification of dysfunctional myocardium by magnetic resonance imaging. A new three-dimensional method for quantitative wall-thickening analysis. Circulation 95:924-931

22. van Rugge FP, Holman ER, van der Wall EE et al (1993) Quantitation of global and regional left ventricular function by cine magnetic resonance imaging during dobutamine stress in normal human subjects. Eur Heart J 14:456-463

23. van der Wall EE, van Dijkman PR, de Roos A et al (1990) Diagnostic significance of gadolinium-DTPA (diethylenetriamine penta-acetic acid) enhanced magnetic resonance imaging in thrombolytic treatment for acute myocardial infarction: its potential in assessing reperfusion. Br Heart $\mathrm{J}$ 63:12-17

24. van Dijkman PR, van der Wall EE, de Roos A et al (1991) Acute, subacute, and chronic myocardial infarction: quantitative analysis of gadolinium-enhanced MR images. Radiology 180:147-151

25. van der Wall EE, Vliegen HW, de Roos A, Bruschke AV (1995) Magnetic resonance imaging in coronary artery disease. Circulation 92:2723-2739

26. van der Hoeven BL, Pires NM, Warda HM et al (2005) Drug-eluting stents: results, promises and problems. Int $\mathbf{J}$ Cardiol 99:9-17

27. van der Geest RJ, Niezen RA, van der Wall EE, de Roos A, Reiber JH (1998) Automated measurement of volume flow in the ascending aorta using MR velocity maps: evaluation of inter- and intraobserver variability in healthy volunteers. J Comput Assist Tomogr 22:904-911

28. van Rugge FP, van der Wall EE, Spanjersberg SJ et al (1994) Magnetic resonance imaging during dobutamine stress for detection and localization of coronary artery disease. Quantitative wall motion analysis using a modification of the centerline method. Circulation 90:127-138

29. van Rugge FP, Boreel JJ, van der Wall EE et al (1991) Cardiac first-pass and myocardial perfusion in normal subjects assessed by sub-second Gd-DTPA enhanced MR imaging. J Comput Assist Tomogr 15:959-965

30. Pluim BM, Lamb HJ, Kayser HW et al (1998) Functional and metabolic evaluation of the athlete's heart by magnetic resonance imaging and dobutamine stress magnetic resonance spectroscopy. Circulation 97:666-672

31. Bax JJ, Lamb H, Dibbets P et al (2000) Comparison of gated single-photon emission computed tomography with magnetic resonance imaging for evaluation of left ventricular function in ischemic cardiomyopathy. Am J Cardiol 86: 1299-1305

32. Langerak SE, Vliegen HW, de Roos A et al (2002) Detection of vein graft disease using high-resolution magnetic resonance angiography. Circulation 105:328-333

33. Marsan NA, Westenberg JJ, Tops LF et al (2008) Comparison between tissue Doppler imaging and velocity-encoded magnetic resonance imaging for measurement of myocardial velocities, assessment of left ventricular dyssynchrony, and estimation of left ventricular filling pressures in patients with ischemic cardiomyopathy. Am J Cardiol 102:1366-1372

34. Grauss RW, Winter EM, van Tuyn J et al (2007) Mesenchymal stem cells from ischemic heart disease patients improve left ventricular function after myocardial infarction. Am J Physiol Heart Circ Physiol 293:H2438-H2447

35. Grauss RW, van Tuyn J, Steendijk P et al (2008) Forced myocardin expression enhances the therapeutic effect of human mesenchymal stem cells after transplantation in ischemic mouse hearts. Stem Cells 26:1083-1093

36. Feng Y, Xie Y, Wang $\mathrm{H}$ et al. (2008) A modified rabbit model of reperfused myocardial infarction for cardiac MR imaging research. Int J Cardiovasc Imaging. doi:10.1007/ s10554-008-9393-2 